OOPEN ACCESS

International Journal of Applied Research in Social Sciences

P-ISSN: 2706-9176, E-ISSN: 2706-9184

Volume 2, Issue 5, P.No. 130-143, November, 2020

Fair East Publishers

Journal Homepage: www.fepbl.com/index.php/ijarss

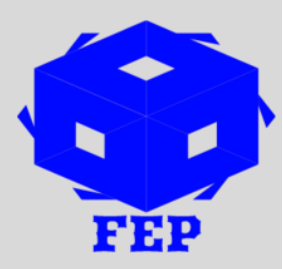

\title{
MODERN SAUDI POETRY: MOHAMMAD HASAN AWWAD'S NIGHT AND ME, IN BALANCE
}

\author{
Yahya Saleh Hasan Dahami ${ }^{1}$ \\ ${ }^{1}$ Associate Professor, English Department - Faculty of Science and Arts, \\ AL BAHA UNIVERSITY - KSA \\ ORCID: https://orcid.org/0000-0003-0195-787
}

*Corresponding Author: Yahya Saleh Hasan Dahami

Corresponding Author Email: dahami02@gmail.com

Article Received: 06-10-20 Accepted: 05-11-20

Published: 25-11-202

Licensing Details: Author retains the right of this article. The article is distributed under the terms of the Creative Commons Attribution-Non Commercial 4.0 License (http://www.creativecommons.org/licences/by-nc/4.0/) which permits non-commercial use, reproduction and distribution of the work without further permission provided the original work is attributed as specified on the Journal open access page.

\begin{abstract}
Arabic poetry is the heart of all types of literature in all Arabic realms. Consistent with this generalization, it can be right that the development of poetry in the modern age, among Arabs, is a positive measure. At that argument, the same would be focused on modern Saudi literature since it is typically considered a central, authoritative, and undivided part of Arabic poetry. In this paper, the researcher has attempted to illustrate some literary aspects of modern Arabic poetry in the Kingdom of Saudi Arabia as an instance of the greatness of Arabic poetry with a particular reference to a contemporary Saudi poet. The study starts with an introduction to the condition of poetry in Arabia. In the first section of the study, the researcher points up the importance of Arabic poetry as an Arabic literature genre. The second section deals with poetry and literary movement in Saudi Arabia as the central section of the investigation. After that, the task moves ahead to deal with a model of the modern Arabic poetry in the kingdom, Mohammad Hasan Awwad, a modernized rebellious poet with stark poetry, then the researcher, analytically and critically, sheds light on some selected verses of one of the poems of Awwad, Night and Me. The study finishes with a discussion and a brief conclusion.
\end{abstract}

Keywords: Arabic literature, Arabic poetry, free verse, greatness, Kingdom of Saudi Arabia, modernism

\section{INTRODUCTION}

Readings in pages of the Arabic literature since the pre-Islamic period is a righthand turning shift to genuineness, rectitude, and originality. It is a return to the principal sources and the 
infinite fountains. The Arabic literature has shined like brilliant stars in the skies of vast Arabic realms for centuries and still in the eyes of considerable numbers of writers, critics, and poets. It is an absolute illustration in the creation, making, and composition of Arabic literature, chiefly poetry, which is composed of elegant historical Mua'llaqat, lyrics, odes, elegies, satires, pride, praise, and the availability of its musical devices.

On all occasions, The Arabs in Arabia are people of valor, gallantry, and daring. Their probing mode and style of life make bravery vigorous. It is believed that the "Arabic-Muslim-speaking people were the major bearers of the torch of culture, knowledge, and civilization throughout the world" (Dahami, 2015; Hitti, 1989: 557). Persistent wanderers, they travel and roam here and there looking for the needed water stream for their living area. Arabs cavalry made their existence from the $4^{\text {th }}$ century. They were and still are talented horsemen.

\section{Arabic Poetry}

Life during pre-Islamic Arabia depended, in no small degree, on generosity, kindness, and cordiality that the encampments would encourage travelers to keep going their way. Consequently, hospitality was a frame of great importance, and the fact that the host reacted appropriately was a distinguished honor and tribute to his tribe or clan. Still, those who elevate and praise Arab traditions and conduct and make the Arabic language's outermost practice are in several instances. As said by Thorndike (1927), "The Arab mind ... is clear and positive, and the Arabic language nervous, virile, and rich both actually and potentially. The old Arabs were acute and observant people" (p. 285).

The Arabs "and their pre-Islamic poetry depict a society that knew about the settled civilizations of their neighbours but did not aspire to join them: rugged manliness was celebrated by the Arabs; silk robes and signet rings were for wimps" (Silverstein, 2010: 7). The Arabs' poet was similarly accustomed to praise and appreciate his tribe in an erudite and intellectual evening exchange and train their offspring. The odes or poems composed in that period are typically short and "conform to strict prosodic rules of meter and rhyme" (Holes, 2004: 11).

The Arabic term Qasayd, a plural of Qasiydah, indicates odes every so often translated as poems instead of prose. Al Mua'llaqat (معلقات), a plural of Mua'llaqah (معلقة), shows 'the hanging poems of Arabs on Al Ka'bah.' It took that title for manifestly being hung up on the Holy Ka'bah in Mecca (also written as Makkah (مكة). Nearly critics, reporters, and scholars state Al Mua'llaqat as the 'seven renowned ones,' for some others ten. The oldest Qasaiyd (قصائد) or poems date back to the period of pre-Islam or what is mistakenly called Al-Jahilliyah, a critical term refers to 'ignorance' designed by the first Muslims to designate the condition of religious and moral sleaze, corruption, and exploitation of pre-Islamic people.

The epoch of the Middle Ages, honestly, was of great value and merit. It saw noteworthy development in several ranges of scientific importance and regard. It is the Arabs, who grasped and apprehended much of Greek philosophy, sciences, and culture that they assimilated and reformulated the learned experience in Arabic formulas to be harmonious with the human attention mentality. Arab-Muslims worked relentlessly in translations and interpretations. One of the crucial sciences that took unique concerns is literature as a measure of Man's acquaintance. "The influence of literature among nations, from a county to another and from a continent to another, is tangible and palpable all over the ages. No one can deny the contribution and influence of Arabic and Islamic civilization on the West" (Dahami, 2017). This influence initiated with the rise and growth of Islam, which saw the light in Makkah but then again 
steadily has expanded in Yathrib (يثرب), later named Al-Medina Al-Monawarah (المدينة الهنورة). In Yathrib, several talented figures accompanied Prophet Mohammad 䶜 and remarkably produced great and elegant Arabic poetry supporting goodness and virtue against evil and wickedness.

The poetic contests where the versifier of the tribe "recited in public his compositions, formed their amusements. They were very sensible to the charms of music, poetry, and oratory, and as a general rule the Arab chieftain was brave, generous, and munificent" (Wilson, 1900: 5). The social task of the pre-Islamic Arabic poet or versifier is to create poetry, typically regarding precise and accurate prosodic rules and assimilating linguistic archaisms as well as syntactic additions. Such social poets speak it out at the annual festival in Souk Okath (عُكاظ), souk (an open-air marketplace near the city of Taif) (the proper Arabic articulation is Okath, though, there are people articulate it as Okaz or Ukaz) near Mecca. The occasion is a regular poetry carnival. The dexterity and ability of the outstanding poets would be existing and held precious to Arabs in their tribal and ethnic daily lives. The situation might be imagined today as the annual artistic Oscar Award of the United States.

Besides, the collective remembrance of community or society is recognized and acknowledged in the character of ash-sha'ir (الثاعر) the poet. As the saluted spokesperson of the community, he had the mission of promoting, elevating, rising, and applauding its protagonists' good deeds, evoking and recalling their descent and lineage, and storming their enemies in war, and lamenting or mourning those who had deceased.

Currently, the historians were and still principally "interested in the Koran, poetry, and genealogy, they have described two main features in pre-Islamic history: the first, the city of Mecca and its sacred shrine, the Ka'bah; the second, the life of the nomads" (Faris, 1946: 43) through the scenery of the sterile but creative, imaginative, and resourceful land as its landscape and with the varied recurrence of few raids and contests for the ownership of a well or the vengeance of a killed kinsman. Certainly, Mecca was a central midpoint in Arabia, and the tribe's life was the most distinctive feature of people and land.

Since the middle ages passing through the Islamic renaissance period in literature and science, and perchance after, with witnesses, proofs and justifications of Holy Mecca and Al-Medina El Monawara, Al Azhar of Cairo, Baghdad of Iraq, Umayyad Masjid in Damascus, Great Masjid of Kirwan in Tunisia, Al Quaraouiyine Masjid of Morocco, Constantinople, the illuminating Andalusia, and many other outstanding specimens and beacons of education, culture, knowledge, and acquaintance in the Arabic world, Arab-Muslims led an entire human civilization. Nations of Arabs used to maintain dominance and supremacy. It is established in the noteworthy land of Arabia, especially in Mecca and Medina, in addition to in Nejd or what is called "the high land of central Arabia, at the time when the earliest extant Arabic literature was produced. There is no doubt that these spoke with all the grammatical inflections. The poetry of the period is sufficient proof" (Chenery, 1869: 12). In the same way, in respect to the point of how we can speak, "Mecca made a nearer approach to the contemporary standard of civilized life than any other settlement in peninsular Arabia" (Hogarth, 1922: 17).

Moreover, Allen (2000), articulates that Arabic poetry has been continuously observed and regarded as the diwan of Arabs (the fountain or rendezvous of Arabs), a literary meeting or gathering in times of joyfulness dejection, conquest, or disgrace. It is a set expression of the Arab people's communal, artistic, logical, cultural, and morals besides high aspirations and 
desires (pp. 65-66). Ash-Shir Diwan Al-Arab (الثعرُ ديوانُ العرب), as stated by Cantrino, (2004), is a famous Arabic set phrase very well-known for all people of Arabs that denotes to the forum of poetry for Arabs. It, as I mentioned earlier, means 'the repository of Arabs.' Probably, it is that there are individuals who do not appreciate its profound connotation but absolutely, all of them are aware of this phrase. "Arabic poetry has always been ... a resort in times of sorrow and happiness, of defeat and victory, an expression of the Arab people's cultural ideals" (Dahami, 2018; Allen, 2000: 65-66).

\section{Poetry and Literary Movement in Saudi Arabia}

The resurgence and renaissance of the Kingdom of Saudi Arabia have commenced with the call and appeal of Imam Muhammad ibn Abdul Wahab. The influence of this call in Saudi literature is perceived in rhetoric, poetry, and literary writings by many Saudi and Arab writers and literary figures. The main influences and inspirations of this resurgence or revival can be realized as historical and educational.

The Kingdom of Saudi Arabia is part of the broad and sizeable Arabic nation. Arabic literature, particularly poetry, was the core of all literary genres in most Arabic countries. According to this overview, it can be true that the evolution of poetry writing in modern Arabic literature is a positive step. At that point, the same would be directed to modern Saudi literature because it is typically considered a fundamental, imperative, and integral part of the Arabic literature. Poetry in Saudi Arabia is a significantly noticeable genre of literature. The prominent genres of Arabic poetry in the Kingdom of Saudi Arabia are love, praise, irony, sarcasm, lamentation, religious, heroic poetry, and several others.

Once both central regions Najd and Hejaz, were unified with other regions under the power of one strong country led by King Abdul Aziz, the newborn Saudi government realized that a crucial element in the prosperity of a nation could be achieved by supporting learning, education, and acquiring knowledge as well as culture. Consequently, the kingdom rushed to launch schools, educational institutions, newspapers, cultural and press media, and many others. One of the early newspapers is Umm Al- Qura newspaper, which started to develop its press in Mecca. The newspaper unlocked ways for the journals and books brought from abroad. Saudi thinkers, intellectuals, academics, and scholars are inspired. Young people activated their passions of thought, reformation, and renovation by their pens under the king's wise support. They had great opportunities and started writing in different literature fields, such as social criticism, literary criticism, and other ranges of thought, philosophy, and literature, especially poetry. The fruits of such endeavors came to light on the pages of Umm Al- Qura, which was a beacon of guidance into knowledge, literature, and Arabic culture.

Furthermore, several papers opened their gates to intellectuals and writers to contribute to the literary movement's progress. Many writers, critics, and literary figures availed such an excellent opportunity to bring inert notions into the public. One of the pioneers who had a good influence is Muhammad Hasan Awwad after the publications of Khawatir Musarraha (خواطر (مصرحه), as well as Adab Al-Hejaz and Al-Ma'rath (المعرض), both were collected and edited by Muhammad Suroor As-Saban.

Several Saudi journals and newspapers contributed to widening the writing circle to broaden the kingdom's literary movement. Al-Manhal magazine, Umm Al- Qura newspaper, The Voice of (Sawt) Al-Hejaz, Al-Medina Al-Munawara were some of the early journals that were launched with the commencement of the new vigorous reign called Saudi Arabia to publish 
different articles, critical essays, stories, poems, contemplative thoughts (خو اطر) and literary reports.

Such papers and printing institutions paved the way for Arab and Saudi intellectuals to start a new career in the making of modern literature in the Kingdom of Saudi Arabia. The initial fruitful source is more apparently and powerfully appeared in Wahy al Sahra (وحي الصحراء), a book by Muhammad Saeed Abd al Maqsuod and Abdullah Balkhair. The significant influence impact engulfs primarily two studies; one is a preface for the book by Muhammad Sa'eed Abdul Maqsood Khoja and Ahmad Al Arabi. In the second, he contributed to a lecture on the literature of Al-Hejaz. The writers, authors, and poets of the first phase of this time followed the phases of Arabic writers of Egypt, Iraq, and some other countries and the poets of migration. Al-Aqqad influenced Awwad in his style, his uprising against the ancient, and his inclination towards the west and its literature.

The majority of the literary figures in the opening phase are admired for their profound-rooted association and correlation of the origin. Their longing of being their language dense and sturdy and their design established with the roots of rhetoric and expression with the excellent edifice. It is well-defined in the writings of Abdul Wahab Ashi, Abdul Rahman ibn Ahmed Al-Sudairy, Abdul Mohsen ibn Abdul Aziz Aal Saud, Ibrahim bin Abdul Rahman ibn Hussein Khafaji, Yahya Tawfiq Hasan, Hasan bin Abdullah Al-Qurashi, Ghazi Abdul Rahman Al-Qusaibi, Husein Sarhan, and several others. The youth got involved with the art when causes of enlightening movement and idealistic consciousness stimulated them. From this milieu, they commenced writing and challenging each other in launching newspapers and journals until the total number of newspapers and journals reached thirty-three in 1372 After Hijra.

The most significant in the stand of artistic lettering and journalistic essays are Al-Manhal magazine and Umm Al-Qura newspaper. When Al-Jazeera magazine appeared in 1379 After Hijra, it took the flag of a high standard and prevailing literary writings. Consequently, it is counted among the motives and goals for the advancement, on the one hand, in the terminology and style and, on the other hand, profundity and intensity in the thoughts. When Al-Jazeera was transformed into a newspaper, it was imitated by other magazines such as Al-Manhal magazine. Al-Yamamah, Al-Arabiya, Al-Faisal, and several others, are those which have been transformed into newspapers. By the end of the $14^{\text {th }}$ century, the genre of essay, literature, and literary criticism reached a lofty place in modern Arabic literature among Arabic countries.

\section{Free Verse}

In 1924, some Arab modern poets such as Amin Raihani and Jubran Khaleel Jubran published a new sort of poetry known as free verse. After two years, in 1926, Mohammad Hasan Awwad followed the previous free verse poets by publishing a verse that went beyond the well-known poetic regulations. Furthermore, the movement of modern poetry - free verse - became wider wherein 1933, Nazik Al-Malaikah contributed to the same genre by issuing her tries in poetry that was in the first of its form, free verse. Moreover, Badr Shakir Al-Saiyab challenged AlMalaikah in this new literature type in general and poetry in particular. At the same time, most of the authors and critics consider her as a pioneer in the field of free verse.

As a matter of fact, some modernist poets have the opinion that they have to invent a new style of poetic literature suitable for the modern age. This final call was to throw away the traditional and congenital poetic forms and create a new record with a couplet built on the free meter or rhythm pattern. Following her, various writers sought a verse to be more accessible from the 
control of rhyme (قافية). Consequently, they called for freedom in wiring poetry without following the classical rhymed poetry; the result is free verse. They started to inscribe broken sentences and to issue them under the mood that it was poetry. All the followers and fans of this new verse assume that they were fetching back Arabic poetry to the modern age and freeing it from the conditions of meter and rhyme.

Awwad is a free verse practitioner and fan. He states that "It is not hidden that what I mean by poetry is the connotation that it stands by the soul; I do not mean speech that is rhythmical and rhymed. Again, and again I say that poetry is not verse" (Habibi, 2012). He is right to define himself well with his ability because I genuinely believe that poetry is not only verse, but my perspective is different from Awwad's. I think that poetry is higher and more glorified than just verse. Poetry has two elements or fundamentals; verse has only one. Poetry advantageously surpasses verse because it comprises (1) meaning but not only meaning, however. It should have a deep or profound meaning that I might call it connotation, not the easy direct denotation, (2) poetry is completed by music, or what is called 'verse' in which verse means the musical or poetical devices needed in poetry. Conversely, verse comprises only the musical or poetical devices. Verse is part of poetry but poetry is not. The idea with Awwad in his comparison between poetry and verse goes the contrary.

The researcher/critic Abdullah Aal Hammad (2015), states, in his paper entitled Homeland among the Renewal Poets in the Kingdom of Saudi Arabia,' that talking about educational and literary rejuvenation as well as renewal and innovation in the Kingdom of Saudi Arabia cannot be impartial and unbiassed without referring to Muhammad Hasan Awwad. Awwad is the voice that proclaimed both in theory and in practice for innovation. Because of this declaration, he encountered severe literary attacks. His rhetorical writings were not far from confiscation or seizure. It is also worth mentioning that his renewal was not to establish aggression and hostility between heritage and modernism. Instead, he called for reading the works of Lebanese writers and the translated works of Westerners. At the same time, he used to admire and praise Ibn Taymiyyah, Ibn Al-Qayyim, Ibn Hazm, Muhammad Abdo, and Muhammad ibn Abd AlWahhab," as it is evident in 'Khawatir Musarraha.'

\section{Awwad: Arabic Modern Poet}

Mohammad Hasan Gasim Awwad is one of the pioneers and innovators who visibly contributed to the appearance of modern free verse, especially in the Kingdom of Saudi Arabia. Whatever the situation is, with the poet's thought or against, he excelled in his profession as a modern poet of free verse. He started this skill so early when he was young and endeavored for his attempts when he was a student.

Several critics believed that Awwad is one of the Saudi leaders of innovative poets, and he is a romantic poet, but he refuses to distinct romanticism from meditation and contemplation. He is a big name and had respectable poems. He is a man of literature, religion who had an accepted education at Al-Falah school, and later on, he was a teacher in the same school. He was learned and taught, like many other Saudi literary figures.

The poet, Mohammad Hasan Awwad, is accounted as one of the leading modernizers and innovators in Arabic literature in Saudi Arabia. He was born in 1320 After Hijra. His father, Hasan Awwad, allowed him to join Al-Falah School. He grew up in Jeddah and worked as a teacher after finishing school. Awwad then joined a few public works such as control and censorship on the imported books and contributed to editing certain journals, for instance, Sawt 
Al-Hijaz. He is also a freelance writer, such as the director of the Chamber of Commerce. In the final stage of his life, he was chosen as the director of the Literary Club of Jeddah until his demise in 1401 After Hijra.

His profession of censorship of books provided him the prospect to increase his background and information about the world of literature, particularly reading books. Hereafter, his connection with the traditional, classical, and conventional culture was very potent and passionate. Nevertheless, he is most affected by what he studied books about contemporary writers, including Arabic literature and Western literature. It gives the idea of his simulation of Al-Aqqad and then his call to think more about western lifestyle and culture by which he was overwhelmed through the translation of literary and social works and figures. He exaggerated his mental mission towards western philosophy, culture, and values. This interest might be seen in his writings and books, principally in Khawatir Musarraha.

Al-Zahrani (2017) stated that a state of arrogance over Arabs and a fondness for the Westerners appeared within the writer Muhammad Hasan Awwad. One of the most vital ailments that afflict intellectuals' speaking or writings is the intense passion for Western culture and development, as two experiences worthy of imitation and emulation, without paying attention to the circumstances, conditions, and reality of the Arabic society. She adds that sometimes such intense infatuation comes on account of being acquainted with Western approaches and theories.

In addition to the ambiguous propaganda in glorifying them with scholarly studies and discussions, it may occur because of travel. The person becomes overwhelmed by a state of transcendence over his own culture, identity, and thought, resulting from the austere comparison between the two situations. As Al Mu'aigili (2015) stated, Muhammad Hasan Awwad is considered one of the most prominent names in the Saudi pioneers' generation, perhaps the most influential of them in his time and the generations that followed. Although Al-Awwad is an eminent poet, his significance and worth primarily might be a phenomenon.

This phenomenon is because of what he is characterized of producing new ideas prior to his generation, and also owing to the manner he presented his ideas to the society in a call for openness to all new, and his frank and strong attack against all what is old which surprised and shocked his contemporary people. Furthermore, Al Mahmoud (2017), goes against the notion of Al Zahrani; he confirms that when Muhammad Hasan Awwad is mentioned, his leadership and uniqueness among the people of his time is also mentioned as well as his unique ability to write in the contexts of communal reform and social progress. It is the issue that the reader realizes clearly in the achievements of Al-Awwad, either poetry or prose.

Nevertheless, such inclination disappeared increasingly as the majority of the writers created their literary character. Some literary and academic writers treated the literary tendency and social delicateness with calm and peaceful elegance like Abdul Wahab Ibraheem Ashi. Some other authors were daring to resist against the classical Arabic tongue and heritage with their pen of harshness and brashness. It is evident in the writings of Muhammad Hasan Awwad, particularly his book Khawatir Musarraha. Awwad's approach was criticized and lashed by some of his contemporary friends like Abdul Wahab Ashi, who stood against the former's fanatism in calling for depending on all that came from the west. Ashi moderately supported the concept of preference of the literary products of Arabic thoughts; the past and the present. 
These were the general issues to be dealt with in social criticism woven within Awwad's time, although writers had diverse modalities of phrase, expression, and saying. All various writers had their design of expression. Their approaches suit them. Each author had his way of demonstration and elucidation reliant on his taste. For instance, Awwad uses a hilarious and sarcastic style, trusting that it is profoundly effective and appealing to the receiver. The cynical idiom is expressed by a method in which the author talks about the elder in the tongue of younger or the language of admiration that exceeds the intention - the other way around, which more frequently rests on the parenthetical sentences of imploring. Sometimes, the author modifies his writing quality and becomes very thoughtful, far away from hilarity, absurdity, and laughter. Sometimes he resorts to the angry, vehement, and oratorical method, or heads towards quite a sober way of writing, in all this, taking into consideration the conditions and rhetoric that suitably places everything in its position.

Awwad is counted as a prose writer but chiefly as a poet. He has some efforts in both areas, starting publishing them in booklets or pamphlets, then they were improved and were published in collections such as:

1- The collection of poetry is composed of two fragments and covers six assortments.

2- The prose collection

3- Some other writings like the music of Gulf poetry and several others

Awwad is a man of innovations and aspires to modernisms. He feels like other Saudi pioneer contemporaries that poetry is not what lecturers and instructors and his contemporaries say or compose; nonetheless, it is different. He imports his meaning for his poetry from the poetry of migrants and the westerns as a result of being highly influenced and impressed by European literature and culture.

According to Awwad, in Arabic poetry, he called to focus on one meaning at a time. He also called to abandon the verse of events and occasions.

Awwad believed Madarsat Al-Diwan and Al-Aqqad as his role examples in some of his opinions and the migrants and western interpreters in some others. Still, he contrasted Al-Aqqad in his criticism and comment on northern migrants, especially in the subject of free verse, as Al-Aqqad strongly rejected this sort of literature.

Awwad has achieved a fair amount of collections in poetry; the most famous are:

1- Diwan Amas wa Atlas (آماس وأطلاس)

2- Diwan Al-Baraem (البر اعم)

3- Diwan Nahwa Keyanin Jadidin (نحو كيان جديد)

4- Diwan Al-Sahir Al-Atheem (الساحر العظيم)

5- Diwan Fi Al-Ufuq Al-Multahab (في الأفث الملتهب)

6- Diwan Rua Ablon (رؤى أبو لون)

When critics and reviewers look at his works, they distinguish the amount of the ability of the poet M. H. Awwad in reaching and implementing what he aspires for. They discover that he could not apply what he believes. He faced difficulties in some of his poems to free them from formats, rhythm, and rhyme.

To the degree that his language is concerned, his writings are considered as a whole. According to the views of some critics, he is free from weakness and unnatural adornments. Awwad did not let the idiomatic language to be used in the language of the verse he composed. However, 
he could not reach the level of attractiveness as some of his rivals like the poet-philosopher Hamza Shehata.

As much as his style and design are concerned, it is measured between strength and weakness. Awwad is like his inspiring guide Al-Aqqad where the design is incapable of walking through even inability to carry it. In the view of some critics, the motive of his linguistic and stylistic flaws goes back to the diversity and multiplicity of poems. He arranged his various poems in different types of poetry, such as philosophy, praise, pride, lament, description, and satire. However, Awwad has criticized social poems, for instance, pessimism, yarn, and others. It can be a privilege that M. H. Awwad let his poems speak around the principles which were well acknowledged in his time and mutual near his modern Saudi and Arab poets.

M. H. Awwad attempted to cover up the arenas of new approaches, especially the innovation (romanticism). He produced a lot in this field and made the sound. However, his best reflections are when he tracked the classics in which he writes on the vanguard of this brand of progressive classic verse. By any means, the prominence of Awwad in abstract poetry is well-identified regardless of all that is mentioned about his poetry. This point elucidates the issue that he is one of the first who moves with the verse from the classical scheme to the open area of innovation. As mentioned earlier, M. H. Awwad was a pioneer and visionary in poetry, but he was also a leader of prose writing. It is stated that he was one of the first literary essay authors in contemporary Saudi literature. He contained a greater field in prose writing since a few writers have gone through. Awwad has considerably backed and contributed to academic, scientific, literary, narrative, creative writing, etc.

By the passage of time, he got the more considerable experience and knowledge in life. His mind became more rational and wiser. Consequently, Awwad's writings are considered to be better and possess a type of wisdom. His famous literary books are Khawatir Musarraha, Min Wahi Al-Hayat Al-Aammah (من وحي الحياة العامة), and Taammulat fi Al-Adab wa Al-Hayaat (تأملات في الأدب و الحياة).

\section{Night and Me: A Modernized Free Verse}

Night and Me - (أنا والليل) is one of the notable and imposing modern Saudi poems by Mohammad Hasan Awwad. I have stated that he is one of the first of the Kingdom of Saudi Arabia poets who protested against the regular meter and rhymes seeking a freestyle. As a modern poet, he claimed that poets in Saudi Arabia, as well as in Arabic countries, need to follow freely this kind of poetry that is named free verse. The new sort of poetry is based on freedom, free from rhyme, and irregular rhythm.

As for what will be the modification in it in rhyme only, like Muwashshah or free verse and the like, the majority of contemporary poets has participated with him, and that is a division or rupture in the scheme of irregular meter, rhythm, and free rhyme which is approved by the centrists of Saudi and Arab writers. The poem, Night and Me, by the poet M. H. Awwad is also of this type; he partially used this and preserved parametric quality. Furthermore, the example of the imaginative and inspired (romantic) movement in which to treat with excessive indulgence in prayers and intermingling with them attempting to escape from realism and run away from people as well as from life.

This poem under study is composed of twenty-two passages, including nine, first ones to poets thought to the night. The poet, M. H. Awwad, defines his feelings and consensuses with the night. In general, we find that the poet uses the literary technique of personification to be able 
to create a conversation between him, a speaker, and the Night whom he bestowed life to be able to speak and share the dialogue. Consequently, the speaker enquires the night, whether it had been conscious of what they talked about. However, he remembers that the object he is talking with is not a body to share his thoughts. And therefore, the poet remains in his discussion with the night even he ended it, leaving the opportunity that the night replies to the poet, followed by a conversation with a pure conscience and integrity that pays for the night.

Night and Me commences with an inquiry to open the gate for the poet pondering in the sky of contemplation. Then the poet retraces his steps to the idea of communicating with the declaration of his conscience. Indeed, in Night and Me, we find a bit of amusement does not melt with some overstatements. I feel that it is necessary to have little comments, analyses, and annotations for some poem lines. The poem starts with the following:

$$
\text { هل أنت مثلي أيهذا الظلامج1 }
$$

Are you comparable to me, O Darkness?

The poet initiates his verse in this poem, Night and Me, with an inquiry. It is a request for information, but the attractive point is that he has a conversation with an object, not a human; the night is personified and given the characteristics of a human to create a portrait of an individual who can share a speech with the poet. The speaker asks if Darkness has any type of fear in this comparison.

تشعر بالويل فتخفي الغرام

Do you feel grief, then hide the passion

The poet associates this verse with the previous verse line. It is also connected with the next as a link of several ideas connected together to illustrate an unsafe feeling from darkness and creating anxiety. This line expresses a state of love mixt with anxiety. More than a picture can be conceived at this point in which the speaker is facing difficulty and fear not because of darkness but perhaps because the type of love of the speaker is unattainable for a reason or another. The speaker, not Darkness, is the one who feels grief, which resulted in hiding his craving.

$$
\text { وتلبس الصمت فتعلو الأنام }
$$

And you put on silence and ascend over creatures

This verse line is still in the same stream of the poet's thought when the speaker clearly discloses his state of distress, not with a slight change to hope or confidence. Astonishingly the poet creates two personifications; one inside the other. As mentioned in the first line, Darkness is the first, and, in this line, silence is the second in which it is Darkness puts on silence. A metaphorical portrait is created to smoothen the state of anxiety presented in the first line. Among Arabs, silence is a means of safety and security. Silence refers to peace, quietness, accord, freedom from strife, calm, tranquility, and serenity. In the previous hemistiches, the meaning is obvious and harmonious; the reader/listener smoothly goes with both musical devices and connotations.

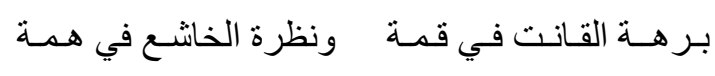

A moment of gratification at the crowning and the judgment of god-fearing man in valor

\footnotetext{
${ }^{1}$ Al-Aof, Issam Basheer, The Encyclopedia
} 
In this verse line, the poet shifts to another abstraction situation as a sign of being stray. $\mathrm{He}$ contemplates a hidden or unknown condition, whether it is about him or Darkness or the implicit beloved. The indication to the beloved is portrayed in the second line yet indirectly when he stated (تنخفي الغرام), which means to hide passion or love. The setting of his circumstance indicates that he is sitting or standing a while on a lofty place - a mountain, a hill, a building but his condition is quiet. When he glimpses from such a high place, the result inside him is mixt with zeal. He is content but for a while, leading him to create a sort of courage. We find alliterative consonance in the Arabic phrasal words (في قمـة), which means on a high spot, and (في همـة), which refers to courage, zeal, or daring.

An idea of the old man (Sheikh), and a soul of the young

$$
\text { وفكرة الثيخ، وروح الصغير }
$$

The end of all previous verse lines stands when the poet adds more abstractive elements to finish his doubtful query with the imaginative Darkness. Awwad continues his abstraction on one idea - love (غرام) - but knows he adds an older man with his wisdom as well as the spirit of the active young. The reader/listener might realize that Awwad wants to send a message that he is all.

Or, are you, Darkness, captivating of hidden danger?

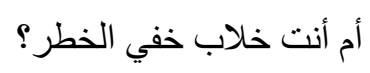

In this verse line, the poet takes up again his interrogative conversation with Darkness. However, the imagined encounter is nothing but an imaginative image. He is asking and answering himself because he is the only one available, realizing, and understanding. The line brings us interesting images about the three characters; Awwad, Darkness, and the beloved/lover in which the poet wants to make sure of his feeling and its stability with strength. It is accepted to imagine that love (غرام) is dangerous when it leads to catastrophes. At the same time, thoughtfully, darkness can be attractive where lovers enjoy the top of joy when they are unseen.

Or, are you, Darkness, lively of yourself, not of human beings?

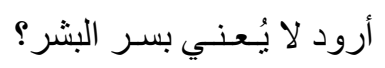

The poet, in his critical writings, supported the idea of neglecting the ancient classical Arabic language. However, in this line, he infringed on his desire. He used an ancient classical expression (أرود) in which many readers will never understand its meaning unless they go back searching in ancient Arabic poetry and dictionaries. By connecting the two lines - this one and the previous - we can say that this word is a noun or adjective, and the adjective is nearer to the context. If the word is a noun, in this case, the meaning is 'time' that does his work in unfulfilled stillness. Nonetheless, if someone says it is an adjective, in this case, the connotative meaning is active, lively, and energetic to go well with the intention of the whole verse line. It illustrates that the speaker when talking with Darkness, realizes that Darkness does not care about the secrets of people in an indication of the ambiguous emotional relation between him and his beloved.

Deceitful, selfish, flatterer, and wicked

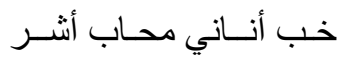

The line is similar in purpose as the previous and connected with it in finishing the idea of the poet, Awwad, who, nobody is sure, whom he defines. Is it Darkness or himself or the beloved? The line is not a sentence, merely managed synonymous words. However, they are significant 
in relating the meaning of the previous lines. The reader/listener might comprehend that the fickle poet used to jump from an image to another as a nature of several modern poets who called for free verse. The judgment can be favorable, praising Awwad's intellectuality. And it can be negative criticizing if not him, his thoughts.

$$
\text { ناء عن الخير كما يزعمون }
$$

Away from goodness as they allege

Awwad is still describing vague images in an assumed conversation, illustrating the poet's thoughts. The previous line is composed of four words to emphasize the preceding ideas. On the contrary, this line is a clause carrying a semi-complete notion that the person is far away from doing any good step, not because he does not want but as the others pretend.

$$
\text { عار عن الروح الذي ينشدون }
$$

Bare of the spirit that they aspire

As the same as the previous line, here, we have extra meaningful clauses indicating a type of contrast with some friends, critics, opponents, or others in which, as he may say, my ambition is not supported by others. It is my own (الغرام) passion that does not concern any. It can be interpreted that his craving or emotion is like the soul I aspire not others. The others can never feel my feelings even if they attempt; they are spiritless in their quest.

$$
\text { هل يعيبك أن تطلب مجد الكبر }
$$

Does it disgrace you seeking the glory of the ancients?

In this last verse line of the extract, the poet concludes with a fascinating picture of glory, dignity, and aspiration of achievement. The subject is hidden as it is the nature of Awwad in the majority of this free verse. Its beauty sometimes is in its ambiguity in which it gives the reader/listener freedom to dive in its profound connotative ideas and metaphors freely. The line is an affirmative clause, but they need to discover that it is a question even without a question mark for thoughtful readers. The speaker draws two probable pictures. The first can be about himself urging and motivating the self to seek the ancient glorified ones' glory. It can be understood that the process is not impossible. The second picture might be understood as a daring question forwarded to his opponents contemptuously asking a question like: do you have the ability to reach the glory and dignity I obtained? Try it!

\section{Discussion}

A point taken against Awwad is that his belief in the eloquent language of Arab is powerless to communicate, but he proved the contrary in his thoughtful free verse. In his critical essays, Awwad attacked some points in society, individually and collectively. However, he did not attain in his verse what he called for. He called for desertion of poetry occasions, but he wrote some of the same kind of poetry that he stood against. Awwad called for the concentration on a solitary connotation at a time in Arabic free verse; however, his verse came without following what he theorized. In writing his verse, he did not contrast the conventional structures of Arabic poetry. Awwad called for social restructuring; nevertheless, all he did in such an area is attacking society and exposed anger; nonetheless, he did not present any instance to be developed or tracked.

Awwad opines that the poet needs to act together with his society by criticizing its conventions and traditions. Both the poet and the community members should be invited towards the modernization of its situations systematically and conventionally. It could be attained, in his opinion, through implementing the customs, traditions, and system of the civilized world, and 
that, as he declared, in the western world but many realized that such notions are mistakenly implemented.

Awwad wanted society to be model and ideal as he comprehends not as others understand. Consequently, his literary, critical, and composed writings were considered violent. He attacked groups of society like literary authors, scholars, and even common men. Many critics stated that his effort was not felicitous with his style, along with his way of thinking. His failure in manner is concerned for the reason that he adopted the violent, overconfidence, harsh expressions as his sources. Another motive of his failure in his mode of thinking is his rejection of all old conventions, traditions, and legacy.

\section{CONCLUSION}

The Arabic poetry is presented as satisfaction and supremacy of phraseology with sparkles of keenness and vision. Commonly, the poem of Muhammad Hasan Awwad might be measured as one of the laudable magnitudes of the literary works in the Kingdom of Saudi Arabia. It contains interesting modern philosophy and culture among Saudi and Arab poets during the twentieth century and after. The poem of Awwad Night and Me had been brought to light as a piece of poetry of exceptional skill. Awwad could fashion shrewdness of amazing impudence. He also could elicit the activeness of appealing essentials and poetic prerequisites. The poem encompassed some powerful and noteworthy responses painstakingly by the improvement of self-assurance. Undeniably, the poetic metaphors, images, and depictions heightening the gifts in modern Saudi poets who significantly contributed to the growth and progress of Saudi and Arabic literature in general and contemporary poetry in particular.

The influential nation is the one that holds the properties of development; that is why the Kingdom of Saudi Arabia has been providing public education with its all regulations free of cost. The matter is not only that but also pays rewards to all students in the sector of higher education. The outcome is prosperity. Furthermore, Saudi Arabia has been seeking its best to amplify and refurbish education at a swift pace. It could be a supreme model for other countries in terms of excellence and keeping the standard.

This study strived through inspecting and reviewing the symbolic and invoking portraits in the verse lines of Muhammad Hasan Awwad, the seeker of modernity and freedom of verse regulations in Saudi Arabia twentieth century. The research attempted to shed light on Arabic poetry's significance, which proved its deep-rooted originality since ancient ages up till today. The study also tried to briefly place literature in the Kingdom of Saudi Arabia as a vital progressing Arabic country supporting learning, literature, and culture and backing modern poets and literary figures. One of them is Muhammad Hasan Awwad, who studiously and thoughtfully contributed to the revival of modernization and modern free verse. Awwad wrote essays on poetry and practicing writing poetry but of his new style of free verse. Night and Me is a specimen of his practice that goes with unique and profound expressions. After the assessment and analysis of the selected verse lines of the poem, it might be decided that it touched substantial and noteworthy results regarding Awwad's ability and talent in activating Arabic poetry as a means of expressing the self and representing the society.

As the evaluating investigation elucidates, the study pursued a reasonable manner associated with the most significant points. The studied verse lines of Muhammad Hasan Awwad are fragments of countless Arabic poetry. Night and Me portrays unique Arab standards, examples, 
and principles towards the rebirth and revival of modern Arabic poetry in the contemporary age.

\section{References}

Aal Hammad, A. (2015). Home among the Renewal Poets in the Kingdom of Saudi Arabia, Journal of King Abdul-Aziz University for Arts and Human Sciences, 22(n/a), 49-81. DOI:10.4197/Art22-3.

Al-Aof, I. $\quad$ B. $\quad$ The Encyclopedia, retrieved from http://awfbooks.com/encyclopedia.php?changePage=page10 (accessed on 18/9/2020) [in Arabic]

Allen, R. (2000). An Introduction to Arabic Literature. Cambridge: Cambridge University Press.

Al Mahmoud, S. A. (2017). Mohammad Hasan Awwad: Questions of Leadership and Creativity. Journal of Arabic and Human Sciences, 11(1), 113-154.

Al Mu'aigili, A. H. (2015). Introductions Sermon in Saudi literature between self-denial and self-affirmation. The Literary Cultural Club in Jeddah, 82(n/a), 7-35.

Al Zahrani, A. A. A. (2017) Authoritarian Discourse Analysis by the Intellectual: The Case of Saudi Writer Mohammad Hasan Awwad. El-Tawassol, 23(52), 81-99.

Cantrino, F. (2004). The Science of Arabic Poetry, Translation: Mohammad Mahdi AshShareef. Beirut: Dar Al Kotob Al Ilmiyah.

Chenery, T. (1869). The Arabic Language: A Lecture. London: Macmillan and Co.

Dahami, Y. S. H. (2018). Tarafah ibn Al-A'bd and his Outstanding Arabic Mua'llagah. International Journal of English Literature and Social Sciences (IJELS), 3(6), 939-947.

Dahami, Y. S. H. (2017). James E. Flecker's Poetic Play "Hassan": The Arab Influence, Aljouf University Social Sciences Journal (AUSSJ), 3(2), 117-129.

Dahami, Y. S. H. (2015). The Contribution of Arab Muslims to the Provencal Lyrical Poetry: The Troubadours in the Twelfth Century. Journal of Arts, King Saud Univ., Riyadh: 27(1), 1-19.

Dyck, E. A. (1894). History of the Arabs and their Literature: Before and After the Rise of Islam. Ig. V. Kleinmayr \& Fed. Bamberg in Laibach.

Faris, N. A. (1946). The Arab Heritage. New Jersey: Princeton University Press at Princeton.

Habibi, M. H. (2012). Al Awwad's Concept of The Living Poetry, Dar of King Abdul-Aziz $38(2), 89-123$.

Hitti, P. K. (1989). History of the Arabs: from the Earliest Times to the Present, $12^{\text {th }}$ reprint, London: Macmillan \& Co. Ltd.

Hogarth, D. G. (1922). Arabia, Oxford: At The Clarendon Press.

Holes, C. (2004). Modern Arabic: Structures, Functions, and Varieties. Washington: Georgetown University Press.

Silverstein, A. J. (2010). Islamic History: A Very Short Introduction. Oxford: Oxford University Press.

Thorndike, L. (1927). A Short History of Civilization. London: John Murray, Albemarle Street, W.

Wilson, E. (1900). Oriental Literature: The Literature of Arabia, Vol. 4. New York: The Colonial Press. 